\title{
Article
}

\section{Sustainability of Machinery Traffic in Vineyard}

\author{
Domenico Pessina *(D), Lavinia Eleonora Galli, Stefano Santoro (D) and Davide Facchinetti (D) \\ Dipartimento di Scienze Agrarie e Ambientali, Università degli Studi, 20133 Milan, Italy; \\ lavinia.galli@unimi.it (L.E.G.); stefano.santoro@unimi.it (S.S.); davide.facchinetti@unimi.it (D.F.) \\ * Correspondence: domenico.pessina@unimi.it; Tel.: +39-02-503-16876
}

Citation: Pessina, D.; Galli, L.E.;

Santoro, S.; Facchinetti, D.

Sustainability of Machinery Traffic in Vineyard. Sustainability 2021, 13, 2475. https://doi.org/10.3390/su13052475

Academic Editors: Eugenio Cavallo, Niccolò Pampuro and Marcella Biddoccu

Received: 19 January 2021

Accepted: 19 February 2021

Published: 25 February 2021

Publisher's Note: MDPI stays neutral with regard to jurisdictional claims in published maps and institutional affiliations.

Copyright: (c) 2021 by the authors. Licensee MDPI, Basel, Switzerland. This article is an open access article distributed under the terms and conditions of the Creative Commons Attribution (CC BY) license (https:// creativecommons.org/licenses/by/ $4.0 /)$.

\begin{abstract}
Viticulture involves significant levels of machinery traffic, causing heavy soil compaction. In particular, the compaction of the subsoil is increased; a deep tillage could certainly solve the problem, but the risk of damage to the plants' root system is high. The aim of this study was to investigate the trend of both the top- and the sub-soil compaction in a hillside vineyard located in Tuscany (Italy), investigating different machine-implement combinations, i.e., self-propelled machinery or narrow tractor coupled to implements. The tests were repeated periodically along the entire growing season, approximately every 6-8 weeks (end of May, end of July and first decade of October). A single test included at least 50 sample measurements, recorded randomly along each inter-row investigated. In the surveyed field, the inter-rows were alternatively covered with grass, or tilled in the top layer during the previous wintertime. Two experimental test sets were developed: the first involved the use of two implements (a sprayer and a grape harvester) towed by narrow tractors, while in the second the pesticide distribution and the harvesting were performed with a properly equipped self-propelled tool carrier. All the other farming operations were executed using the same implements in both cases. Balanced use of the self-propelled tool carrier and the traditional tractor-implement combination allows a better distribution of the soil compaction (in particular in the top-soil), thus improving the root-growing efficiency.
\end{abstract}

Keywords: compaction; top-soil; sub-soil; self-propelled tool carrier; narrow tractor

\section{Introduction}

Soil compaction is one of the major problems facing modern agriculture [1]; it is related to soil aggregates, because it alters the spatial arrangement, size and shape of clods and aggregates and consequently the pore spaces both inside and between these units [2]. Moreover, it is significantly reflected in the reduction of the fertility and production capabilities of the soil [3].

In perennial crops (as well as in forestry [4]), compaction is also aggravated by the difficulty of soil structure restoration through tillage operations, both in the top- and subsoil, which may require implements not suitable for work among the rows; moreover, deep tillage could damage heavily the roots of plants.

Plant root form, length distribution, radius distributions, branching, and overall plant vigor have all been demonstrated to be heavily influenced by soil structure. Similarly, characterization of soil structure has shown that plant roots and their associated chemical and biological environments are strong determinants of the character of soil structure [5].

Compacted soils can affect crop root growth and the soil water-holding capacity, reduce nutrient uptake and make the growing crops more prone to diseases. All these effects can lower final crop yields. Compacted soil is much more prone to soil erosion and run-off [6].

In highly mechanized viticulture, the tractor could pass among the rows up to 22 times per year in the vineyards traditionally cultivated, and 20\% less in grass-covered fields [7]. The effect on soil compaction and both hydrological and erosional processes of machinery traffic were widely investigated on a sloping vineyard [8]. On the other hand, it was 
ascertained that sub-soil compaction in a vineyard is mostly to be attributed to machinery wheel load [9]. According to some studies [10-12], the wheel axle load, the number of passages over the same track, the soil state during the passage and above all the soil moisture content significantly affect the local soil compaction. Moreover, quite a strong effect on soil compaction in the wheel track in relation to the number of wheel passages was found [13].

The effect of wheel load (11, 15 and $33 \mathrm{kN})$ and tyre inflation pressure $(70,100$ and $150 \mathrm{kPa}$ ) was also investigated [14]; in this case, the tyre inflation pressure had the greatest influence on stress values under wheel at a depth of $0.1 \mathrm{~m}$, and small influence at depth values of $0.3 \mathrm{~m}$ and deeper. The loading highlighted an opposed behaviour, changing significantly the stress in deeper layers. Similar results were reported in other investigations $[15,16]$, where the soil density in the tyre passage track at depth $0.2 \mathrm{~m}$ increased with an increase in wheel loading and inflation pressure, and decreased with an increase in the speed of passage. On the other hand, different inter-row management, with periodic tillage or grass covering involved careful studies about runoff and soil loss in sloping vineyard [17]. The evaluation of the soil compaction in vineyards can be carried out by means of in situ soil strength measurements, for example with a portable penetrometer [18].

The aim of this study was to investigate the trend of both the top- and sub-soil compaction in a hillside vineyard located in Tuscany (Italy), in subsequent periods along an entire growing season. The soil penetration resistance was measured in some inter-rows, by using two different machine combinations, as follows:

- a classical solution, traditionally used by wine growers in Tuscany, represented by narrow tractors coupled with towed implements;

- or, as an alternative, a self-propelled tool carrier equipped with equivalent implements to carry out the same operations.

The details of machinery used and the operations carried out are shown in Section 2.

\section{Materials and Methods}

The tests were carried out in a vineyard inside of the "Chianti Classico DOC" district, located in the Castellina in Chianti municipality, Siena province (Tuscany, Italy), latitude $43^{\circ} 28^{\prime} 9^{\prime \prime} 12 \mathrm{~N}$, longitude $11^{\circ} 17^{\prime} 19^{\prime \prime} 32 \mathrm{E}$, altitude above sea level $572 \mathrm{~m}$. The vines (Sangiovese, Cabernet Sauvignon and Merlot varieties) have an average age of about 30 years. The cultivating density is 4000 plants/ha, resulting from a pattern of $2.5 \mathrm{~m}$ between rows and $1 \mathrm{~m}$ along the row, with wooden poles. In the previous wintertime, a top-soil tillage was carried out on alternate inter-rows, by using a sub-soiler. The surveyed field, named "Le piazze" (located inside of the "Gretole" vineyard), was divided into two experimental areas, separated by a buffer zone of $10 \mathrm{~m}$, in which the experimental data were not recorded. The soil analysis detected a silty-clay-loam soil type [18], with a remarkable amount of calcareous skeleton. The average slope of the vineyard is about $8 \%$. More soil details of the surveyed field are shown in Table 1.

The soil penetration resistance was measured with an electronic penetrometer driven manually, equipped with a $30^{\circ}$ inclination cone of $1 \mathrm{~cm}^{2}$ total base area, as defined in ASAE S313.3 [19] and ASAE EP542 [20]. The penetrometer, make Eijkelkamp, model Penetrologger, is composed by a measuring needle interchangeable tip, a load cell (to detect the force), an ultrasonic sensor (for measuring the penetration depth) and a set of electronics including a microprocessor, a GPS module, a memory module and a battery pack. The measurements were carried out both in inter-rows covered with grass or previously tilled in the top-soil. A single test included at least 50 sample measurements, recorded randomly along each inter-row investigated. Ten to 12 inter-rows for each testing condition were investigated. Some samples were also performed in the wheel ruts, created both by the narrow tractors and the self-propelled tool carriers. Standard statistical parameters (means, standard deviation, student $t$-test) were considered to evaluate the significance of the results. 
Table 1. Main soil physical and chemical features of the surveyed field "Le piazze", located inside of the "Gretole" vineyard).

\begin{tabular}{|c|c|}
\hline Feature & Value \\
\hline \multirow{4}{*}{ Texture } & Sand: $20.0 \%$ \\
\hline & Silt: $46.5 \%$ \\
\hline & Clay: $33.5 \%$ \\
\hline & Skeleton: $60.9 \mathrm{~g} / \mathrm{kg}$ \\
\hline $\mathrm{pH}$ & 8.45 \\
\hline Salinity & $0.237 \mathrm{mS} / \mathrm{cm}$ \\
\hline Total limestone & $236 \mathrm{~g} / \mathrm{kg}$ \\
\hline Active limestone & $126 \mathrm{~g}\left(\mathrm{CaCO}_{3}\right) / \mathrm{kg}$ \\
\hline Organic carbon & $0.4 \%$ \\
\hline Organic matter & $0.7 \%$ \\
\hline Cation exchange capacity & $19.5 \mathrm{mEq} / 100 \mathrm{~g}$ \\
\hline $\mathrm{N}$ tot & $0.89 \mathrm{~g} / \mathrm{kg}$ \\
\hline P2O5 (assimilable) & $1.93 \mathrm{mg} / \mathrm{kg}$ \\
\hline Ca (exchangeable) & $3757.0 \mathrm{mg} / \mathrm{kg}$ \\
\hline Mg (exchangeable) & $302.0 \mathrm{mg} / \mathrm{kg}$ \\
\hline K20 (exchangeable) & $147.0 \mathrm{mg} / \mathrm{kg}$ \\
\hline Fe (exchangeable) & $7.20 \mathrm{mg} / \mathrm{kg}$ \\
\hline
\end{tabular}

To ascertain the initial soil condition, and consequently to obtain a reference to be compared to the following surveying campaigns, a preliminary set of measurement was carried out on the first decade of April, before any machinery passage into the vineyard for the considered growing season. The subsequent compaction measurements were carried out every approximately 6-8 weeks (end of May, end of July and first decade of October, this last after the grape harvesting). In the year of the tests, the monthly rainfall trend is shown in Figure 1; the min/max air temperature trend is shown in Figure 2. The soil moisture content (wet basis) were measured at the time of the tests campaigns, for the two layers $0-30 \mathrm{~cm}$ and $30-60 \mathrm{~cm}$, both for the tilled and grass-covered inter-rows (Table 2).

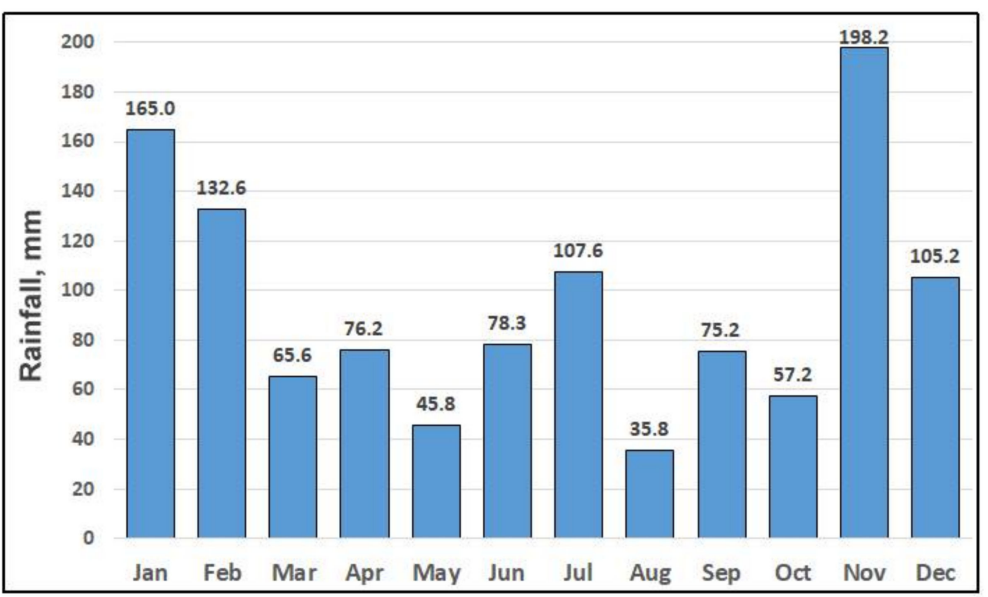

Figure 1. Monthly rainfall trend in the surveyed field. 


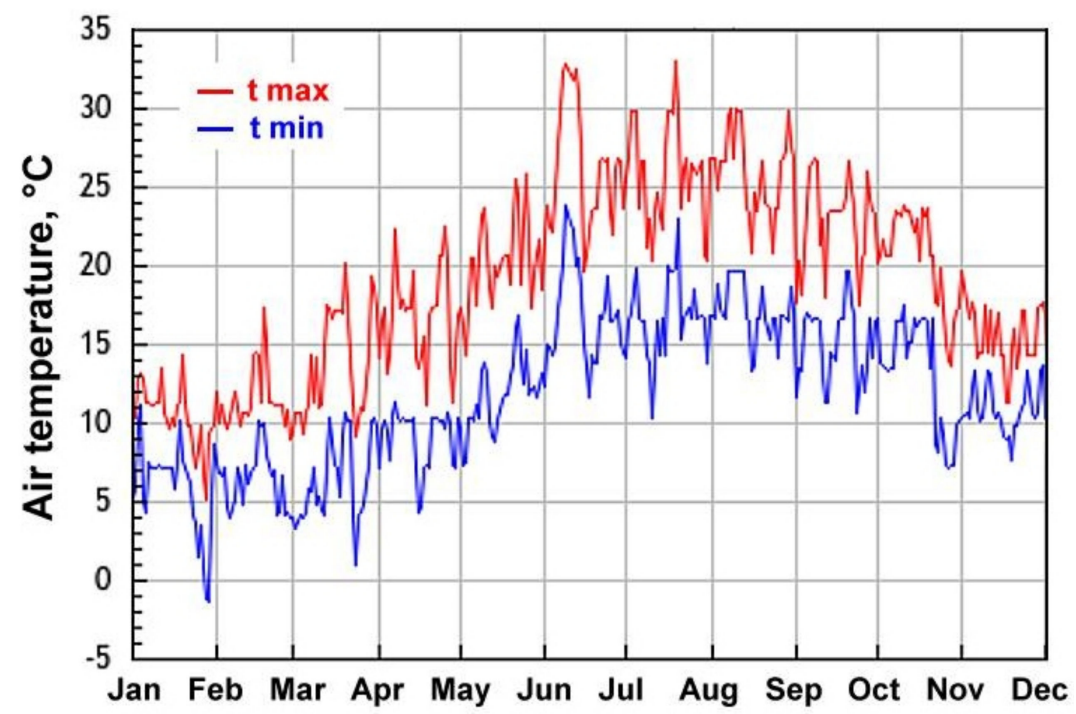

Figure 2. Min/max air temperature trend in the surveyed field.

Table 2. Soil moisture content of the soil in the surveyed field, along the entire growing season.

\begin{tabular}{ccccc}
\hline Period & \multicolumn{2}{c}{ Soil Moisture Content (w.b.), \% } \\
\hline & \multicolumn{2}{c}{$\begin{array}{c}\text { Tilled } \\
\text { Inter-Rows }\end{array}$} & \multicolumn{2}{c}{$\begin{array}{c}\text { Covered by Grass } \\
\text { Inter-Rows }\end{array}$} \\
\hline & $0-30 \mathrm{~cm}$ & $30-60 \mathrm{~cm}$ & $0-30 \mathrm{~cm}$ & $30-60 \mathrm{~cm}$ \\
\hline first decade of April & 20.5 & 21.2 & 21.3 & 21.6 \\
\hline end of May & 14.7 & 19.0 & 15.4 & 19.3 \\
\hline end of July & 13.5 & 16.3 & 14.3 & 16.7 \\
\hline first decade of October & 11.8 & 14.2 & 12.8 & 14.4 \\
\hline
\end{tabular}

Apart from the pesticide treatments and the grape harvesting, all the other agricultural tasks were carried out using the same machinery, working in identical operating conditions. More in detail, a 4WD narrow tractor make Lamborghini model RF90 was used in the traditional combination, coupled to a towed pneumatic sprayer, make KWH, model B612, for the pesticide treatments and a towed grape harvester, make Pellenc, model 8050, for the grape harvesting (Table 3). In the self-propelled combination, a tool carrier, make Pellenc, model 3300, was fitted with a pneumatic sprayer module, make Cima, model Spider for the pesticide treatments, and a self-propelled grape harvester module make Pellenc, model 4560, for the grape harvesting. In both combinations, along the entire growing season a total of 14 passes for pesticide treatments and one pass for the grape harvesting were executed.

Table 3. Main technical characteristics of the machinery combinations involved in the surveyed vineyard cultivation.

\begin{tabular}{ccccc}
\hline Combination & \multicolumn{2}{c}{ Traditional } & \multicolumn{2}{c}{ Self-Propelled } \\
\hline $\begin{array}{c}\text { Machinery } \\
\text { Coupling } \\
\text { Detail }\end{array}$ & $\begin{array}{c}\text { Narrow Tractor/ } \\
\text { Towed Pneumatic } \\
\text { Sprayer }\end{array}$ & $\begin{array}{c}\text { Narrow } \\
\text { Tractor/ } \\
\text { Towed Grape } \\
\text { Harvester }\end{array}$ & $\begin{array}{c}\text { Self-propelled } \\
\text { Tool Carrier/ } \\
\text { Pneumatic } \\
\text { Sprayers Module }\end{array}$ & $\begin{array}{c}\text { Self-propelled } \\
\text { Tool Carrier/Grape } \\
\text { Harvester Module }\end{array}$ \\
\hline Make & $\begin{array}{c}\text { Lamborghini/ } \\
\text { KWH }\end{array}$ & Lamborghini/Pellenc & Pellenc/Cima & Pellenc/Pellenc \\
\hline Model & RF 90/B612 & RF 90/8050 & 3300/Spider & $3300 / 4560$ \\
\hline
\end{tabular}


Table 3. Cont.

\begin{tabular}{|c|c|c|c|c|}
\hline Combination & \multicolumn{2}{|c|}{ Traditional } & \multicolumn{2}{|c|}{ Self-Propelled } \\
\hline Tyres & $\begin{array}{c}\text { tr. front } 300 / 70 \mathrm{R} 20 \\
@ 220 \mathrm{kPa} \\
\text { tr. rear } 420 / 70 \mathrm{R} 28 \\
@ 160 \mathrm{kPa} \\
\text { sprayer } \\
10.0 / 75-15.3 \\
@ 280 \mathrm{kPa}\end{array}$ & $\begin{array}{c}\text { tr. front } 300 / 70 \mathrm{R} 20 \\
@ 220 \mathrm{kPa} \\
\text { tr. rear. } 420 / 70 \mathrm{R} 28 \\
@ 160 \mathrm{kPa} \\
\text { harv. } 16.0 / 70-20 \\
@ 320 \mathrm{kPa}\end{array}$ & $\begin{array}{l}\text { front } 420 / 70 \mathrm{R} 24 \\
@ 240 \mathrm{kPa} \\
\text { rear } 600 / 55 \mathrm{R} 26.5 \\
@ 160 \mathrm{kPa}\end{array}$ & $\begin{array}{l}\text { front } 420 / 70 \mathrm{R} 24 \\
@ 240 \mathrm{kPa} \\
\text { rear } 600 / 55 \mathrm{R} 26.5 \\
@ 160 \mathrm{kPa}\end{array}$ \\
\hline Mass, kg & $\begin{array}{l}\text { empty 3130/715 } \\
\text { full load 3130/1990 }\end{array}$ & $\begin{array}{l}\text { empty } 3130 / 3040 \\
\text { full load } 3130 / 5400\end{array}$ & $\begin{array}{l}\text { empty 5130/1550 } \\
\text { full load 5130/3550 }\end{array}$ & $\begin{array}{l}\text { empty } 5130 / 2850 \\
\text { full load } 5130 / 5570\end{array}$ \\
\hline
\end{tabular}

\section{Results and Discussion}

The soil penetration resistance results are shown in Figures 3 and 4 and in Tables 4 and 5 (respectively for the "tilled" and "covered by grass" inter-rows).

For a more effective comparison, according to [14], the penetration resistance data were averaged for layers of $10 \mathrm{~cm}$ depth, thus allowing a better comparison for similar layers in subsequent periods along the growing season.

The "reference" data refer to the situation ascertained at the beginning of the growing season, before any passage of the machinery into the vineyards for that season, obviously common for both the traditional and self-propelled combinations.

The quite high standard deviation values found for the penetrometer readings might be ascribed to the high percentage of coarse fraction of the soil and its structure variability, naturally wide [21]. In any case, values of standard deviation similar to those obtained are reported, for example, in [5,21-24].

In the tilled inter-rows and after the 1st period, the difference in compaction caused by the traditional and the self-propelled machinery combinations is not so evident, being significant only in $21-30 \mathrm{~cm}$ and $31-40 \mathrm{~cm}$ layers, because the sub-soiler is working to a nominal depth of about $18-20 \mathrm{~cm}$.

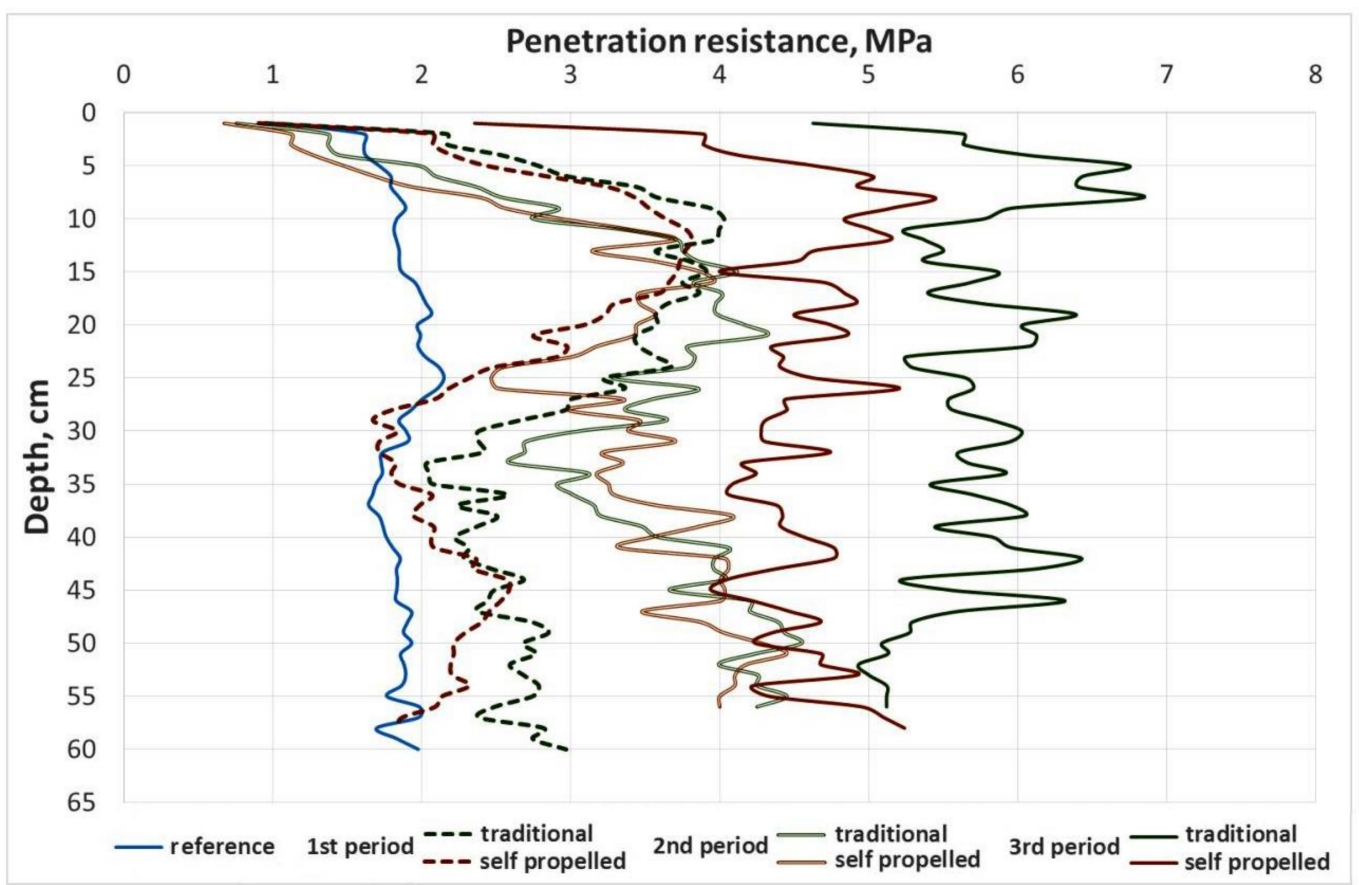

Figure 3. Soil penetration resistance values recorded along the different periods in the growing season for the traditional and self-propelled machinery combinations, in the tilled inter-rows. 


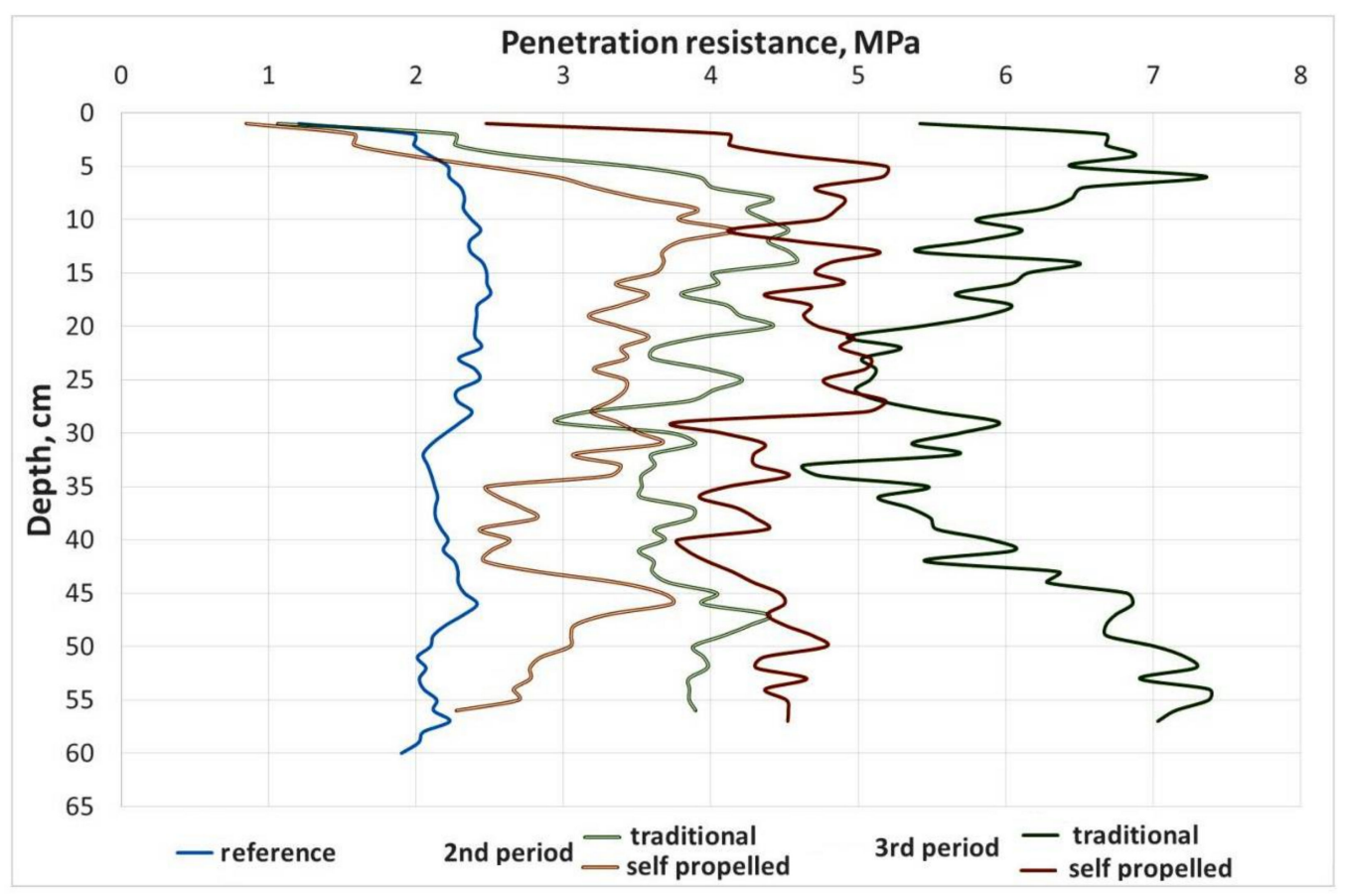

Figure 4. Soil penetration resistance values recorded along the different periods of the growing season for the traditional and self-propelled machinery combinations, in the inter-rows covered by grass (N.B. = 1st period data are missing).

Table 4. Soil penetration resistance values recorded along the different periods in the growing season for the traditional and self-propelled machinery combinations in the tilled inter-rows, averaged for layers of $10 \mathrm{~cm}$ thickness each.

\begin{tabular}{|c|c|c|c|c|c|c|c|c|c|c|c|c|c|c|}
\hline \multirow{3}{*}{$\begin{array}{c}\text { Layer } \\
\text { Depth, } \\
\text { cm }\end{array}$} & \multirow{2}{*}{\multicolumn{2}{|c|}{ Reference }} & \multicolumn{4}{|c|}{ After 1st Period } & \multicolumn{4}{|c|}{ After 2nd Period } & \multicolumn{4}{|c|}{ After 3rd Period } \\
\hline & & & \multicolumn{2}{|c|}{ Traditional } & \multicolumn{2}{|c|}{ Self-Prop. } & \multicolumn{2}{|c|}{ Traditional } & \multicolumn{2}{|c|}{ Self-Prop. } & \multicolumn{2}{|c|}{ Traditional } & \multicolumn{2}{|c|}{ Self-Prop. } \\
\hline & $\begin{array}{l}\text { pen. } \\
\text { res., } \\
\text { MPa }\end{array}$ & s.d. & $\begin{array}{l}\text { pen. } \\
\text { res., } \\
\text { MPa }\end{array}$ & s.d. & $\begin{array}{l}\text { pen. } \\
\text { res., } \\
\text { MPa }\end{array}$ & s.d. & $\begin{array}{l}\text { pen. } \\
\text { res., } \\
\mathrm{MPa}\end{array}$ & s.d. & $\begin{array}{l}\text { pen. } \\
\text { res., } \\
\text { MPa }\end{array}$ & s.d. & $\begin{array}{l}\text { pen. } \\
\text { res., } \\
\text { MPa }\end{array}$ & s.d. & $\begin{array}{l}\text { pen. } \\
\text { res., } \\
\mathrm{MPa}\end{array}$ & s.d. \\
\hline $1-10$ & 1.68 & 0.70 & 2.86 & 1.68 & 2.63 & 1.40 & 1.96 & 1.48 & $1.72 *$ & 1.12 & 6.01 & 2.31 & $4.42 *$ & 2.25 \\
\hline $11-20$ & 1.92 & 0.60 & 3.77 & 1.32 & 3.57 & 1.27 & 3.86 & 1.67 & 3.55 & 1.85 & 5.66 & 2.56 & $4.70 *$ & 2.24 \\
\hline $21-30$ & 2.00 & 0.66 & 3.21 & 1.47 & $2.33 *$ & 1.31 & 3.66 & 1.93 & $3.05 *$ & 1.77 & 5.71 & 2.49 & $4.53 *$ & 2.14 \\
\hline $31-40$ & 1.73 & 0.63 & 2.29 & 1.26 & $1.91 *$ & 0.93 & 3.03 & 1.52 & $3.50 *$ & 2.06 & 5.75 & 2.53 & $4.33 *$ & 1.98 \\
\hline $41-50$ & 1.86 & 0.61 & 2.53 & 1.00 & 2.39 & 0.80 & 4.12 & 1.44 & 3.90 & 1.61 & 5.76 & 2.50 & $4.39 *$ & 2.02 \\
\hline $51-60$ & 1.87 & 0.54 & 2.68 & 0.71 & $2.16 *$ & 0.67 & 3.93 & 0.96 & 4.05 & 0.75 & 4.39 & 2.06 & 4.55 & 1.77 \\
\hline
\end{tabular}

${ }^{*}=$ statistically significant difference per $p<0.05$ (test $\mathrm{T}$ ) between the traditional and self-propelled combinations data. The relevant values are in bold.

The tests carried out after the 2nd period showed minimum differences in the first 2 layers (from 0 to $20 \mathrm{~cm}$ ). At a higher depth $(21-30 \mathrm{~cm}$ ) the traditional machinery produce a slightly higher compaction, while going deep $(31-40 \mathrm{~cm})$ the self-propelled combination causes a slightly higher compaction. From 40 to $60 \mathrm{~cm}$ the trend is quite similar for the two conditions.

The results obtained at the end of the 3rd period (after the grape harvesting) in the tilled inter-rows highlight a remarkably reduced compaction (with a difference sometime exceeding 1.5 MPa) of the self-propelled combination, along almost the entire soil profile. Although with small discrepancies, the data recorded in the inter-rows covered by grass confirm the described trend.

Unfortunately, for the inter-rows covered by grass the data to be recorded after the 1st period were missed, because the soil was compacted too much to be penetrated by exerting the sole manual force of the operator. This was mainly due to a long previous 
period with no rain (and no integration of irrigation), and consequently a very low soil moisture content. By contrast, in the two following test campaigns (2nd and 3rd period) the differences found were in almost all the cases statistically significant (apart the 21-30 cm layer in the 2nd period), always in favour of the self-propelled combination.

In general, the critical compaction value for the crops growing reported in [5] of 3.5 MPa was exceeded in several tests, as expected partly after the 2 nd period, but above all after the 3rd period.

Table 5. Soil penetration resistance values recorded along the different periods of the growing season for the traditional and self-propelled machinery combinations in the inter-rows covered by grass, averaged for layers of $10 \mathrm{~cm}$ thickness each.

\begin{tabular}{|c|c|c|c|c|c|c|c|c|c|c|c|c|c|c|}
\hline \multirow{3}{*}{$\begin{array}{c}\text { Layer } \\
\text { Depth, } \\
\mathrm{cm}\end{array}$} & \multicolumn{2}{|c|}{ Reference } & \multicolumn{4}{|c|}{ After 1st Period } & \multicolumn{4}{|c|}{ After 2nd Period } & \multicolumn{4}{|c|}{ After 3rd Period } \\
\hline & & & \multicolumn{2}{|c|}{ Traditional } & \multicolumn{2}{|c|}{ Self-Prop. } & \multicolumn{2}{|c|}{ Traditional } & \multicolumn{2}{|c|}{ Self-Prop. } & \multicolumn{2}{|c|}{ Traditional } & \multicolumn{2}{|c|}{ Self-Prop. } \\
\hline & $\begin{array}{l}\text { pen. } \\
\text { res., } \\
\text { MPa }\end{array}$ & s.d. & $\begin{array}{l}\text { pen. } \\
\text { res., } \\
\text { MPa }\end{array}$ & s.d. & $\begin{array}{l}\text { pen. } \\
\text { res., } \\
\text { MPa }\end{array}$ & s.d. & $\begin{array}{l}\text { pen. } \\
\text { res., } \\
\text { MPa }\end{array}$ & s.d. & $\begin{array}{l}\text { pen. } \\
\text { res., } \\
\text { MPa }\end{array}$ & s.d. & $\begin{array}{l}\text { pen. } \\
\text { res., } \\
\text { MPa }\end{array}$ & s.d. & $\begin{array}{l}\text { pen. } \\
\text { res., } \\
\text { MPa }\end{array}$ & s.d. \\
\hline $1-10$ & 2.10 & 0.81 & \multirow{6}{*}{\multicolumn{4}{|c|}{ n.d. }} & 3.27 & 1.71 & 2.58 * & 1.53 & 6.45 & 2.24 & $4.48 *$ & 2.12 \\
\hline $11-20$ & 2.43 & 0.74 & & & & & 4.26 & 1.91 & $3.58 *$ & 1.93 & 5.89 & 2.27 & $4.66 *$ & 2.03 \\
\hline $21-30$ & 2.34 & 0.85 & & & & & 3.71 & 1.90 & 3.38 & 1.93 & 5.26 & 2.42 & $4.76 *$ & 2.32 \\
\hline $31-40$ & 2.13 & 0.97 & & & & & 3.67 & 2.01 & $2.93 *$ & 1.90 & 5.33 & 2.79 & $4.22 *$ & 1.81 \\
\hline $41-50$ & 2.25 & 1.01 & & & & & 3.88 & 1.56 & 3.09 * & 1.50 & 6.40 & 2.49 & $4.33 *$ & 2.33 \\
\hline $51-60$ & 2.08 & 0.79 & & & & & 3.89 & 1.22 & 2.66 * & 1.05 & 7.02 & 1.74 & $4.32 *$ & 2.57 \\
\hline
\end{tabular}

${ }^{*}=$ statistically significant difference per $p<0.05$ (test T) between the traditional and self-propelled combinations data. The relevant values are in bold; n.d. $=$ not detected.

In any case, the evolution of the soil compaction over time was quite interesting: in the tilled inter-rows and between the 1st and 2nd periods a decrease was recorded in the superficial layers, probably due to the rain that improved the regeneration capacity of the top-soil. By contrast, in the sub-soil a progressive increasing compaction was clearly detected along the entire growing season.

No comparisons were unfortunately carried out in the inter-rows covered by grass after the 1st period, due to the impossibility of obtaining experimental data. In any case, in the following two periods a similar increase of the soil compaction was detected.

Although this was not the main goal of this paper, in Tables 6 and 7 the data of tilled and covered by grass inter-rows are compared, respectively for the self-propelled and traditional combinations.

Table 6. Soil penetration resistance values recorded along the different periods of the growing season for the self-propelled machinery combination, averaged for a layer of $10 \mathrm{~cm}$ depth.

\begin{tabular}{|c|c|c|c|c|c|c|c|c|c|c|c|c|c|c|c|c|}
\hline \multirow{3}{*}{$\begin{array}{c}\text { Layer } \\
\text { Depth, } \\
\text { cm }\end{array}$} & \multicolumn{4}{|c|}{ Reference } & \multicolumn{4}{|c|}{ After 1st Period } & \multicolumn{4}{|c|}{ After 2nd Period } & \multicolumn{4}{|c|}{ After 3rd Period } \\
\hline & \multicolumn{2}{|c|}{ Grassed } & \multicolumn{2}{|c|}{ Tilled } & \multicolumn{2}{|c|}{ Grassed } & \multicolumn{2}{|c|}{ Tilled } & \multicolumn{2}{|c|}{ Grassed } & \multicolumn{2}{|c|}{ Tilled } & \multicolumn{2}{|c|}{ Grassed } & \multicolumn{2}{|c|}{ Tilled } \\
\hline & $\begin{array}{l}\text { pen. } \\
\text { res., } \\
\text { MPa }\end{array}$ & s.d. & $\begin{array}{l}\text { pen. } \\
\text { res., } \\
\text { MPa }\end{array}$ & s.d. & $\begin{array}{l}\text { pen. } \\
\text { res., } \\
\text { MPa }\end{array}$ & s.d. & $\begin{array}{l}\text { pen. } \\
\text { res., } \\
\text { MPa }\end{array}$ & s.d. & $\begin{array}{l}\text { pen. } \\
\text { res., } \\
\text { MPa }\end{array}$ & s.d. & $\begin{array}{l}\text { pen. } \\
\text { res., } \\
\text { MPa }\end{array}$ & s.d. & $\begin{array}{l}\text { pen. } \\
\text { res., } \\
\text { MPa }\end{array}$ & s.d. & $\begin{array}{l}\text { pen. } \\
\text { res., } \\
\text { MPa }\end{array}$ & s.d. \\
\hline $1-10$ & 2.10 & 0.81 & $1.68 *$ & 0.70 & \multirow{6}{*}{\multicolumn{2}{|c|}{ n.d. }} & 2.63 & 1.40 & 2.58 & 1.53 & $1.72 *$ & 1.12 & 4.48 & 2.12 & 4.42 & 2.25 \\
\hline $11-20$ & 2.43 & 0.74 & $1.92 *$ & 0.60 & & & 3.57 & 1.27 & 3.58 & 1.93 & 3.55 & 1.85 & 4.66 & 2.03 & 4.70 & 2.24 \\
\hline $21-30$ & 2.34 & 0.85 & 2.00 & 0.66 & & & 2.33 & 1.31 & 3.38 & 1.93 & 3.05 & 1.77 & 4.76 & 2.32 & 4.53 & 2.14 \\
\hline $31-40$ & 2.13 & 0.97 & $1.73 *$ & 0.63 & & & 1.91 & 0.93 & 2.93 & 1.90 & $3.50 *$ & 2.06 & 4.22 & 1.81 & 4.33 & 1.98 \\
\hline $41-50$ & 2.25 & 1.01 & 1.86 & 0.61 & & & 2.39 & 0.80 & 3.09 & 1.50 & 3.90 * & 1.61 & 4.33 & 2.33 & 4.39 & 2.02 \\
\hline $51-60$ & 2.08 & 0.79 & 1.87 & 0.54 & & & 2.16 & 0.67 & 2.66 & 1.05 & $4.05^{*}$ & 0.75 & 4.32 & 2.57 & 4.55 & 1.77 \\
\hline
\end{tabular}

$*$ = statistically significant difference per $p<0.05$ (test $\mathrm{T}$ ) between the data relevant to the inter-rows tilled and covered by grass. To highlight the relevant values these are in bold; n.d. $=$ not detected. 
Table 7. Soil penetration resistance values recorded along the different periods of the growing season for the traditional machinery combination, averaged for layer of $10 \mathrm{~cm}$ depth.

\begin{tabular}{|c|c|c|c|c|c|c|c|c|c|c|c|c|c|c|c|}
\hline \multirow{3}{*}{$\begin{array}{c}\text { Layer } \\
\text { Depth, } \\
\text { cm }\end{array}$} & \multicolumn{4}{|c|}{ Reference } & \multicolumn{3}{|c|}{ After 1st Period } & \multicolumn{4}{|c|}{ After 2nd Period } & \multicolumn{4}{|c|}{ After 3rd Period } \\
\hline & \multicolumn{2}{|c|}{ Grassed } & \multicolumn{2}{|c|}{ Tilled } & Grassed & \multicolumn{2}{|c|}{ Tilled } & \multicolumn{2}{|c|}{ Grassed } & \multicolumn{2}{|c|}{ Tilled } & \multicolumn{2}{|c|}{ Grassed } & \multicolumn{2}{|c|}{ Tilled } \\
\hline & $\begin{array}{l}\text { pen. } \\
\text { res., } \\
\text { MPa }\end{array}$ & s.d. & $\begin{array}{l}\text { pen. } \\
\text { res., } \\
\text { MPa }\end{array}$ & s.d. & $\begin{array}{l}\text { pen. } \\
\text { res., } \\
\text { MPa }\end{array}$ & $\begin{array}{l}\text { pen. } \\
\text { res., } \\
\text { MPa }\end{array}$ & s.d. & $\begin{array}{l}\text { pen. } \\
\text { res., } \\
\text { MPa }\end{array}$ & s.d. & $\begin{array}{l}\text { pen. } \\
\text { res., } \\
\text { MPa }\end{array}$ & s.d. & $\begin{array}{l}\text { pen. } \\
\text { res., } \\
\text { MPa }\end{array}$ & s.d. & $\begin{array}{l}\text { pen. } \\
\text { res., } \\
\text { MPa }\end{array}$ & s.d. \\
\hline $1-10$ & 2.10 & 0.81 & $1.68 *$ & 0.70 & \multirow{6}{*}{ n.d. } & 2.86 & 1.68 & 3.27 & 1.71 & $1.96^{*}$ & 1.48 & 6.45 & 2.24 & $6.01 *$ & 2.31 \\
\hline $11-20$ & 2.43 & 0.74 & $1.92 *$ & 0.60 & & 3.77 & 1.32 & 4.26 & 1.91 & $3.86 *$ & 1.67 & 5.89 & 2.27 & 5.66 & 2.56 \\
\hline $21-30$ & 2.34 & 0.85 & 2.00 & 0.66 & & 3.21 & 1.47 & 3.71 & 1.90 & 3.66 & 1.93 & 5.26 & 2.42 & 5.71 & 2.49 \\
\hline $31-40$ & 2.13 & 0.97 & $1.73 *$ & 0.63 & & 2.29 & 1.26 & 3.67 & 2.01 & $3.03 *$ & 1.52 & 5.33 & 2.79 & 5.75 & 2.53 \\
\hline $41-50$ & 2.25 & 1.01 & 1.86 & 0.61 & & 2.53 & 1.00 & 3.88 & 1.56 & 4.12 & 1.44 & 6.40 & 2.49 & $5.76^{*}$ & 2.50 \\
\hline $51-60$ & 2.08 & 0.79 & 1.87 & 0.54 & & 2.68 & 0.71 & 3.89 & 1.22 & 3.93 & 0.96 & 7.02 & 1.74 & $4.39 *$ & 2.06 \\
\hline
\end{tabular}

The technical characteristics of the machines travelling in the vineyard notably affect the structural characteristics between the soil tilled or covered by grass.

As expected, in the "reference" period the penetration resistance is quite low in the very superficial layer if compared with that of the deeper layers; these low values were also confirmed after the other periods, although they are generally higher. With the selfpropelled combination, the trend is in line with what is reported in the literature [5,25] for tilled inter-rows.

The test carried out after the 3rd period showed no statistically significant differences for the self-propelled combination in the tilled and grassed inter-rows.

\section{Conclusions}

Both the data recorded in the tilled and grass-covered inter-rows confirm statistically that the traditional machinery combination causes a higher soil compaction in respect to the self-propelled combination, above all when many passages into the vineyard are carried out.

In fact, notwithstanding their higher mass, the use of self-propelled machinery instead of the traditional combination of tractors coupled to towed implements is able to reduce the compaction due to the machinery traffic in the vineyard, at least in the soil and climatic conditions surveyed in the tests campaign described.

In fact, the total mass values, both of the spraying ( $8680 \mathrm{~kg}$ vs. $5120 \mathrm{~kg},+69 \%)$ and the harvesting set-ups $(10,750 \mathrm{~kg}$ vs. $8530 \mathrm{~kg},+26 \%)$ were higher, but the larger tyre contact area of the self-propelled machine lead to a lower mean pressure on the soil.

For the grape harvesting in particular, the mass of the towed grape harvester is charged only over two wheels, and not over 4 wheels as happens for the self-propelled machine.

The towed grape harvester has a mass of $5400 \mathrm{~kg}$ at full load, charging for approximately $85 \%$ (about $4600 \mathrm{~kg}$ ) on two tyres $16.0 / 70-20$, having a section width of approximately $400 \mathrm{~mm}$. As a consequence, to support adequately the resultant load per wheel of $2300 \mathrm{~kg}$ (at a max speed of $40 \mathrm{~km} / \mathrm{h}$ ), each tyre is characterized by a strong carcass stiffness (equivalent to 10 ply rating) and, therefore, must be inflated at a high pressure $(320 \mathrm{kPa})$.

By contrast, the self-propelled grape harvester is equipped with wide section tyres, suitable for working at low inflation pressure, thus creating a large contact area.

In accordance with some dedicated models available on literature (e.g., [26]), it should be possible to ascertain the contact area value in each operating condition, in order to calculate the mean pressure on the soil, to be then compared to the real soil compaction.

Other question is the repeated passes of the machinery on the soil, and how they affect the compaction, taking also into account the sensitivity of the terrain regarding the structural conditions (texture, moisture content, skeleton amount, etc.). 
Apart from the pesticide treatments and the grape harvesting, in the surveyed vineyard 12 more tasks (such as topping, tying, leaf-stripping, etc.) were carried out during the growing season, using traditional combinations of tractor-implement. When studying the compaction produced by the self-propelled machinery, the contribution to the soil compaction of the passes for these further operations was not directly taken into account, because the tests were generally conducted only inside the ruts created by the tyres. In fact, the self-propelled machinery produces typically just one rut located in the centre of each inter-row, by contrast with the couple of ruts created by the pass of the tractor and the towed implement, that are situated towards the borders of the inter-row. This could have made worsen the results obtained with the traditional combination, as already highlighted in [13].

In any case, a balanced use of self-propelled machinery and of the traditional tractorimplement combination allows a better distribution of the soil compaction (in particular in the top-soil), so improving the root growing efficiency [27]. Nevertheless, it should be necessary to ascertain the possible qualitative and quantitative differences of yield in the two working conditions.

Climate plays a vital role in the terroir of a given wine region, as it strongly controls canopy microclimate, vine growth, vine physiology, yield, and berry composition, which together determine wine attributes and typicity. New challenges are, however, predicted to arise from climate change, as grapevine cultivation is deeply dependent on weather and climate conditions [28].

The ongoing climate change will not favour also the best physical status of the soil structure in vineyards, due to the foreseeable long drought periods, as well as the heavy rains that increasingly affect the current climate. This will worsen the natural compaction, to which is added the compaction caused by human labour, first and foremost that of machinery.

However, many parameters can affect crop productivity, but undoubtedly the compaction is one of the most important. Its limitation can be pursued primarily with a decrease in the passage number of the machinery. Apart from extreme cases, where animal (horse) draught instead of tractor is used, this can be achieved with combinations of tractor and multiple implements (to be fitted in the front and at the rear of the tractor), to be carried out possibly in periods of the growing season when the soil is less sensitive to compaction.

Even the use of wide section and low-pressure tyres can help the compaction reduction, especially that of the top-soil. Finally, restoring a suitable content of organic matter in the soil (ideally $4 \%$ ) can certainly help improve its physical structure, making it less sensitive to compaction. The organic matter distribution can be carried out both thanks to the use of organic matrices (manure, compost, solid digestate), and with agricultural practices specifically intended for this purpose, such as green manure.

Author Contributions: Conceptualization and methodology, D.P. and D.F.; testing, validation and formal analysis, L.E.G. and S.S.; writing and editing, D.P. All authors have read and agreed to the published version of the manuscript.

Funding: This research received no external funding.

Institutional Review Board Statement: Not applicable.

Informed Consent Statement: Not applicable.

Data Availability Statement: Not applicable.

Conflicts of Interest: The authors declare no conflict of interest.

\section{References}

1. Hamza, M.A.; Anderson, W.K. Soil compaction in cropping systems-A review of the nature, causes and possible solutions. Soil Tillage Res. 2005, 82, 121-145. [CrossRef]

2. Defossez, P.; Richard, G. Models of soil compaction due to traffic and their evaluation. Soil Tillage Res. 2002, 67, 41-64. [CrossRef] 
3. Burg, P.; Zemànek, P.; Turan, J.; Findura, P. The penetration resistance as a soil degradation indicator in the viticulture. Acta Univ. Agric. Silvi. Medel. Brun. 2012, 8, 29-36. [CrossRef]

4. Spinelli, R.; Magagnotti, N.; Cavallo, E.; Capello, G.; Biddoccu, M. Reducing soil compaction after thinning work in agroforestry plantations. Agrofor. Syst. 2019, 93, 1765-1779. [CrossRef]

5. Pierret, A.; Moran, C.J. Plant Roots and Soil Structure. In Encyclopedia of Agrophysics. Encyclopedia of Earth Sciences Series; Gliński, J., Horabik, J., Lipiec, J., Eds.; Springer: Dordrecht, The Netherlands, 2011. [CrossRef]

6. Finch, H.J.S.; Samuel, A.M.; Lane, G.P.F. Soils and soil management. In Woodhead Publishing Series in Food Science, Technology and Nutrition, Lockhart $\mathcal{E}$ Wiseman's Crop Husbandry Including Grassland, 9th ed.; Woodhead Publishing: Cambridge, UK, 2014; pp. 37-62. [CrossRef]

7. Lisa, L.; Parena, S.; Lisa, L. Working times and production cost of grapes in grass covered or tilled vineyards of Piedmont. In Proceedings of the VIII GESCO Meeting, Vairão, Portugal, 3-5 July 1995; pp. 325-330.

8. Capello, G.; Biddoccu, M.; Ferraris, S.; Cavallo, E. Effects of Tractor Passes on Hydrological and Soil Erosion Processes in Tilled and Grassed Vineyards. Water 2019, 11, 2118. [CrossRef]

9. Van Dijck, S.J.E.; Van Asch, T.W.J. Compaction of loamy soils due to tractor traffic in vineyards and orchards and its effect on infiltration in southern France. Soil Tillage Res. 2002, 63, 141-153. [CrossRef]

10. Håkansson, I.; Medvedev, V.M. Protection of soils form mechanical overloading by establishing limits for stress cause by heavy vehicles. Soil Tillage Res. 1995, 35, 85-97. [CrossRef]

11. Dawidowski, J.B.; Morrison, J.E.; Snieg, M. Measurement of soil layer strength with plate sinkage and uniaxial confined methods. Trans. ASAE 2001, 44, 1059-1064. [CrossRef]

12. Canillas, E.C.; Salokhe, V.M. Modeling compaction in agricultural soils. J. Terramech. 2002, 39, 71-84. [CrossRef]

13. Buliński, J.; Sergiel, L. Effect of wheel passage number and tyre inflation pressure on soil compaction in the wheel track. Ann. Warsaw Univ. Life Sci. SGGW Agric. 2013, 5, 15-62. Available online: https://www.cabdirect.org/cabdirect/abstract/20143130163 (accessed on 8 February 2021).

14. Arvidsson, J.; Keller, T. Soil stress as affected by wheel load and tyre inflation pressure. Soil Tillage Res. 2007, 96, 284-291. [CrossRef]

15. Carman, K. Compaction characteristics of towed wheels on clay loam in soil bin. Soil Tillage Res. 2002, 65, 37-43. [CrossRef]

16. Carman, K. Prediction of soil compaction under pneumatic tires using a fuzzy logic approach. J. Terramech. 2008, 45, 103-108. [CrossRef]

17. Bagagiolo, G.; Biddoccu, M.; Rabino, D.; Cavallo, E. Effects of rows arrangement, soil management, and rainfall characteristics on water and soil losses in Italian sloping vineyards. Environ. Res. 2018, 166, 690-704. [CrossRef] [PubMed]

18. Soil Survey Staff, Natural Resources Conservation Service, USDA. Soil Series Classification Database. 2019. Available online: https:/ / www.nrcs.usda.gov/wps/portal/nrcs/detail/soils/survey/class/data/?cid=nrcs142p2_053583 (accessed on 8 February 2021).

19. ASAE. ASAE Standards 4E. S313.2: Soil Cone Penetrometer; ASAE: St. Joseph, MI, USA, 1999.

20. ASAE. ASAE Standards 4E. EP542: Procedures for Obtaining and Reporting Data with the Soil Cone Penetrometer; ASAE: St. Joseph, MI, USA, 1999.

21. Van Huyssteen, L. Interpretation and use of penetrometer data to describe soil compaction in vineyards. S. Afr. J. Enol. Vitic. 1983, 2, 59-65. [CrossRef]

22. Alesso, C.A.; Masola, M.J.; Carrizo, M.E.; Cipriotti, P.A.; del Imhoff, S. Spatial variability of short-term effect of tillage on soil penetration resistance. Arch. Agron. Soil Sci. 2019, 65, 822-832. [CrossRef]

23. Carrara, M.; Castrignanò, A.; Comparetti, A.; Febo, P.; Orlando, S. Mapping of penetrometer resistance in relation to tractor traffic using multivariate geostatistics. Geoderma 2007, 142, 294-307. [CrossRef]

24. Utset, A.; Cid, G. Soil penetrometer resistance spatial variability in a Ferralsol at several soil moisture conditions. Soil Tillage Res. 2001, 61, 193-202. [CrossRef]

25. Peacock, B. Managing compacted soils in vineyards. In Symposium on University of California Cooperative Extension; pub. GV8-97; University of California: Tulare County, CA, USA, 1999; Available online: http:/ / cetulare.ucanr.edu/ files/82002.pdf (accessed on 8 February 2021).

26. Febo, P.; Lucarelli, F.; Pessina, D. Soil-tyre interaction parameters influencing soil compaction-A study of contact area prediction models. In Advanced in Geoecology 32; Subsoil Compaction; Horn, R., van den Akker, J.J.H., Arvidsson, J., Eds.; IUSS: Vienna, Austria, 2000; Available online: https:/ / d-nb.info/958575282/04 (accessed on 8 February 2021)ISBN 3-923381-44-1.

27. Buliński, J.; Sergiel, L. Soil consideration in cultivation of plants. Ann. Warsaw Univ. Life Sci. SGGW Agric. 2013, 5, 15-61.

28. Santos, J.A.; Fraga, H.; Malheiro, A.C.; Moutinho-Pereira, J.; Dinis, L.-T.; Correia, C.; Moriondo, M.; Leolini, L.; Dibari, C.; Costafreda-Aumedes, S.; et al. A Review of the Potential Climate Change Impacts and Adaptation Options for European Viticulture. Appl. Sci. 2020, 10, 3092. [CrossRef] 